\title{
Isolation and characterization of mycobacteria from striped bass Morone saxatilis from the Chesapeake Bay
}

\author{
Martha W. Rhodes ${ }^{1, *}$, Howard Kator ${ }^{1}$, Ilsa Kaattari ${ }^{1}$, David Gauthier ${ }^{1}$, \\ Wolfgang Vogelbein ${ }^{1}$, Christopher A. Ottinger ${ }^{2}$ \\ ${ }^{1}$ Department of Environmental and Aquatic Animal Health, Virginia Institute of Marine Science, College of William and \\ Mary, Gloucester Point, Virginia 23062, USA \\ ${ }^{2}$ United States Geological Survey, Leetown Science Center, National Fish Health Research Laboratory, Kearneysville, West \\ Virginia 25430, USA
}

\begin{abstract}
Mycobacteriosis in striped bass Morone saxatilis of Chesapeake Bay, USA, was first diagnosed in 1997 based on the presence of granulomatous inflammation and acid-fast bacteria in skin and spleen. To confirm histopathology, bacteriological detection and identification of mycobacteria were begun using splenic tissue from fish with and without skin ulcerations. On the basis of initial studies using a variety of selective and nonselective media, decontamination, homogenization and incubation conditions, a simple and quantitative recovery method using aseptic necropsy of splenic tissue was developed. Optimal recovery was obtained by spread-plating homogenates on Middlebrook $7 \mathrm{H} 10$ agar with incubation for $3 \mathrm{mo}$ at $23^{\circ} \mathrm{C}$. Mycobacteria were recovered from $76 \%$ ( $\mathrm{n}=149 / 196$ ) of fish examined. Mycobacterial densities exceeded $10^{4}$ colony forming units $\cdot \mathrm{g}$ tissue ${ }^{-1}$ in $38 \%$ of samples $(n=63 / 168)$ that were examined using a quantitative approach. The most frequently recovered mycobacterium, present in $57 \%(\mathrm{n}=109 / 192)$ of characterized samples, was the recently named new species Mycobacterium shottsii. Polyinfections of $M$. shottsii and other mycobacteria were observed in $25 \%$ of samples $(n=47 / 192)$ with densities of $M$. shottsii usually 1 or more orders of magnitude higher than co-isolate(s). Other mycobacteria recovered included isolates that, based on phenotypic traits, resembled $M$. interjectum, $M$. marinum, $M$. scrofulaceum, $M$. szulgai and M. triplex. M. marinum, commonly associated with fish mycobacteriosis and human disease, was recovered infrequently $(3 \%, n=6 / 192)$. The presence of multiple mycobacterial types occurring at high densities suggests that a variety of mycobacteria could be causative agents of mycobacteriosis in striped bass from the Chesapeake Bay. Striped bass is the major recreational fish species in the Chesapeake Bay, and the significance of the current epizootic to human health and the potential adverse effects on fish stocks are not known.
\end{abstract}

KEY WORDS: Mycobacteriosis · Fish disease $\cdot$ Striped bass $\cdot$ Morone saxatilis $\cdot$ Mycobacterium marinum $\cdot$ Mycobacterium shottsii

\section{INTRODUCTION}

Striped bass Morone saxatilis are the basis of an important commercial and recreational fish resource, particularly along the Atlantic coast of the United States. The Chesapeake Bay states of Maryland and Virginia account for more than half of the total US landings of striped bass and realize economic benefits

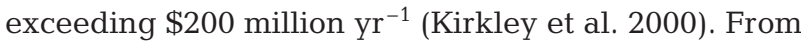
the mid-1970s to the mid-80s there was a steep decline in striped bass landings, presumably due to overfishing, which resulted in an inter-state fisheries management program which also included restocking efforts (Anonymous 1981). Striped bass populations reboun- 
ded during the early to mid-1990s but by the late 1990s concern for the health of these fish returned. An epizootic in Chesapeake Bay striped bass, characterized by skin lesions and granulomatous inflammation with associated acid-fast bacteria, was first described in 1997 (Baya 1998, Vogelbein et al. 1998). Bacterial diseases in striped bass exhibiting skin lesions and scale loss have been attributed to a variety of aetiologies, including Aeromonas, Edwardsiella, Flexibacter, Pseudomonas, and Vibrio spp. (Toranzo et al. 1983, Mitchell 1984, Sindermann 1988, Plumb 1991, Baya et al. 1997). However, in the current epizootic the presence of nonbranching acid-fast bacteria within granulomas implicated mycobacteria as the causative agent and represented the first time that fish mycobacteriosis had been reported in the Chesapeake Bay or along the Atlantic Coast of the United States.

The mycobacterial species frequently associated with disease in fish are Mycobacterium abscessus (formerly $M$. chelonae subsp. abscessus), M. chelonae, $M$. fortuitum and M. marinum (Belas et al. 1995). Less frequently isolated species include $M$. neoarum, $M$. poriferae, M. scrofulaceum, and M. simiae (Backman et al. 1990, Lansdell et al. 1993, Tortoli et al. 1996).

However, our understanding of pathogenic mycobacteria involved in wild fish mycobacteriosis remains poor for a number of reasons. A presumptive diagnosis of piscine mycobacteriosis is often made based on histological findings, and culture is not attempted or is unsuccessful due to the fastidious nature of the organisms or inappropriate culture conditions. Cultural methods are also sensitive to contamination, and the ease of introducing saprophytic mycobacteria into fish tissues during necropsy complicates identification of pathogenic strains. Decontamination has been employed to remove background microbiota in clinical (Kent \& Kubica 1985) and environmental (Dalsgaard et al. 1992, Chinabut 1999) samples but can adversely affect mycobacterial recovery (Brooks et al. 1984, Schulze-Röbbecke et al. 1991).

Mycobacterium marinum was isolated during an outbreak of mycobacteriosis in cultured striped bass (Hedrick et al. 1987) and from wild striped bass collected in San Pablo-San Francisco Bay waters and adjacent Pacific Ocean areas (Lansdell et al. 1993). Histological prevalences ranging from 25 to $68 \%$ were reported for epizootics of mycobacteriosis in wild populations of Pacific striped bass (Sakanari et al. 1983). Although cultured diseased striped bass occasionally exhibited external lesions, none were reported for wild populations. Two previously unknown mycobacteria, M. shottsii (Rhodes et al. 2001, 2003) and 'M. chesapkeaki' (Heckert et al. 2001) have been isolated from Chesapeake Bay striped bass during the current epizootic.
This paper describes the types and prevalences of mycobacteria isolated during the current epizootic in striped bass collected from Virginia waters of the Chesapeake Bay. To circumvent the need for decontamination and provide quantitative data, an isolation and enumeration method was developed based on aseptic necropsy of splenic tissue and direct plating on a relatively nonselective medium. Although incubation periods were lengthy, the simple procedure required little specialized equipment or techniques and provided for both enumeration and detection of polyinfections.

\section{MATERIALS AND METHODS}

Fish. Striped bass were collected from the Chesapeake Bay and its tributaries ranging from the Potomac River to the Bay entrance. Collection methods included hook and line by recreational fishermen, whereas haul seine, pound nets or trawl surveys were conducted by personnel of the Virginia Institute of Marine Science (VIMS) Department of Fisheries Science.

Necropsy. The majority of samples $(n=44)$ collected early in the study, from December 1997 through October 1998, were obtained from trawl surveys. These initial samples consisted of diseased fish which had been internally sexed prior to bacteriological analyses, precluding aseptic sampling. Excised splenic tissue was immersed in $70 \% \mathrm{EtOH}$ for $5 \mathrm{~min}$, drained, and the residual alcohol allowed to evaporate prior to tissue homogenization. Tissue from these samples was decontaminated as described below.

All subsequent samples collected from June 1999 through November 2001 ( $\mathrm{n}=196$ ) included both healthy appearing fish and fish exhibiting clinical signs, i.e. presence of scale loss, pigmentation and ulceration. Exterior surfaces were disinfected with $70 \%$ EtOH prior to necropsy and samples of internal tissue collected aseptically. Spleen and liver were sampled from 18 fish to compare frequency of mycobacterial detection between the 2 sites. Skin scrapings from lesions of selected fish were removed using a scalpel.

Total length, weight and gross clinical signs were recorded for each fish.

Tissue homogenization. Dermal and internal tissue samples were homogenized in 2 to $3 \mathrm{ml}$ Butterfield's buffer (BB) (Anonymous 1995) using a Ten Broeck tissue grinder. Approximately 1 to $2 \mathrm{~g}$ of spleen was used to prepare homogenates in the initial group of samples, and was reduced to ca. 0.1 to $0.5 \mathrm{~g}$ for subsequent samples. Skin samples were less than $0.1 \mathrm{~g}$. Mycobacterial densities $\left(g\right.$ tissue $^{-1}$ ) were calculated from the weight of tissue used in each homogenate.

Homogenate decontamination. Skin and internal tissue samples requiring decontamination were pro- 
cessed using one or more of the following methods. Replicate $1 \mathrm{ml}$ aliquots of homogenate were centrifuged at $4000 \times g$ at $4{ }^{\circ} \mathrm{C}$ for $30 \mathrm{~min}$ and pellets resuspended in $1 \mathrm{ml} 0.3 \%$ Zephiran $^{\mathrm{TM}}$ (Sanofi Winthrop Pharmaceuticals) (Method A), $\% \mathrm{NaOH}$ (Method B) or $2 \% \mathrm{HCl}$ (Method $\mathrm{C}$ ). After $15 \mathrm{~min}$ exposure to acid or base in Methods B and C, suspensions were centrifuged as above, pellets resuspended in BB containing the $\mathrm{pH}$ indicator bromocresol purple, and neutralized by addition of either $1 \% \mathrm{HCl}$ or $\mathrm{NaOH}$ until a blue color persisted ( $\mathrm{pH}$ 6.8). Neutralized suspensions were centrifuged and resuspended in 0.5 to $1 \mathrm{ml} \mathrm{BB}$. After $2 \mathrm{~h}$ exposure to Zephiran ${ }^{\mathrm{TM}}$, suspensions were centrifuged, washed twice with $\mathrm{BB}$ and resuspended in $\mathrm{BB}$.

Processing of skin lesions was modified in subsequent samples to reduce total exposure time to potential detrimental effects of the selected decontaminant, $2 \% \mathrm{NaOH}$, by neutralization prior to centrifugation. Skin scrapings from selected fish with external granulomatous lesions were homogenized in $1 \mathrm{ml} \mathrm{BB}$ and decontaminated with a final concentration of $2 \%$ $\mathrm{NaOH}$ for $15 \mathrm{~min}$. Treated homogenates were neutralized by addition of $0.5 \% \mathrm{HCl}$ as described above. Suspensions were centrifuged and resuspended in $1 \mathrm{ml} \mathrm{BB}$ and spread-plated onto Middlebrook 7H10 agar(MDA) containing $0.5 \%$ glycerol and oleic acid, albumin, dextrose and catalase (OADC) or albumin, dextrose and catalase (ADC) enrichment (Difco, Becton Dickson Diagnostic Systems).

Decontamination of pure culture suspensions. Pure cultures of mycobacteria isolated from striped bass were grown at $30^{\circ} \mathrm{C}$ in Middlebrook $7 \mathrm{H} 9$ broth (MDB) containing OADC enrichment (Difco) and 0.05\% Tween 80, adjusted to an absorbance of $\mathrm{OD}_{590}=0.1$, and subsequently diluted 50- or 500-fold in phosphate buffer. Fifty $\mu \mathrm{l}$ aliquots were added to duplicate microfuge tubes containing $450 \mu \mathrm{l} 2 \% \mathrm{HCl}, 2 \% \mathrm{NaOH}$, $0.3 \%$ Zephiran $^{\mathrm{TM}}$ or buffer (control). After $45 \mathrm{~min}$ exposure to acid or base, treated suspensions were neutralized. Neutralized suspensions and controls were pelleted and washed once in phosphate buffer. Bacterial suspensions exposed to Zephiran ${ }^{\mathrm{TM}}$ for $2 \mathrm{~h}$ were diluted 2-fold in buffer, pelleted and washed twice. Pellets were resuspended in $500 \mu \mathrm{l}$ buffer and bacteria enumerated by spread plating the treated suspension and 10 -fold dilutions thereof in duplicate to MDA. Plates were incubated at $30^{\circ} \mathrm{C}$ for $6 \mathrm{wk}$.

Culturing of mycobacteria. Decontaminated homogenates $(0.1$ to $0.2 \mathrm{ml})$ from the initial group of samples $(\mathrm{n}=44)$ were inoculated onto Lowenstein-Jensen (LJ) slants (BBL, Becton Dickson Diagnostic Systems) and Brain Heart Infusion agar (BHI) (Difco) plates containing $5 \%$ sheep red blood cells (BA), MDA and MDA modified to contain $0.025 \%$ malachite green, $0.04 \%$ cycloheximide and $0.0035 \%$ nalidixic acid (MMDA) (Teska et al. 1997). Inoculated media were incubated at $30^{\circ} \mathrm{C}$. Agar plates were examined using a stereoscopic microscope at 1 to $2 \mathrm{wk}$ intervals for $2 \mathrm{mo}$. All morphologically distinct colonies were examined for acid-fastness (Ziehl-Neelsen) and acid-fast colonies streaked to MDA to obtain purified cultures. Growth on LJ slants was streaked to MDA plates and examined for acid fastness.

Tissue homogenates from aseptically sampled internal sites of fish $(\mathrm{n}=196)$ and selected skin homogenates prepared using reduced exposure to $\mathrm{NaOH}$ were spread plated on MDA with ADC or OADC. Duplicate spread plates inoculated with homogenate and serial 10-fold dilutions thereof were used to provide a quantitative estimate of mycobacterial density for 168 of the 196 samples. Homogenates were also spread plated onto BHI agar to monitor for contamination by heterotrophic bacteria. Incubation temperature was reduced to $23^{\circ} \mathrm{C}$, the incubation period extended to 3 mo and plates were examined as described above. Plates positive for both mycobacteria and non-acid-fast colonies on BHI suggested that either contamination or infection by a nonmycobacteria had occurred. These data were excluded from further analysis.

Phenotypic characterization of isolates. Acid-fast colonies selected from the primary isolation and enumeration plates were purified by streaking. Growth on MDA at 23,30 and $37^{\circ} \mathrm{C}$ was compared to determine the preferred growth temperature and pigment production. Purified isolates were characterized using the following biochemical and growth tests (Kent \& Kubica 1985, Master 1995): production of arylsulfatase, nitrate reductase, niacin, pyrazinamidase, semi-quantitative and heat-stable catalase $\left(68^{\circ} \mathrm{C}\right)$, Tween 80 hydrolysis and urease. Tests were conducted at the preferred growth temperature. Isolates were grouped into major types according to pigment production, niacin and nitrate reactions. Diagnostic keys (Lévy-Frébault \& Portaels 1992, Master 1995, Tortoli 2003) were used to assign isolates to an existing species when possible.

Isolates $(n=17)$ representing the most frequently encountered types were processed for HPLC (Butler et al. 1996) and mycolic acid profiles analyzed as described previously (Butler \& Guthertz 2001).

Quantification of mycobacteria. Mycobacterial densities were expressed as colony forming units $(\mathrm{CFU}) \cdot \mathrm{g}$ tissue $\mathrm{e}^{-1}$ and means calculated from log-transformed data. Mean values preceded by ' $<$ ' indicated that at least one of the replicate samples was below the detection limit and values preceded by ' $>$ ' indicated that colonies at the highest dilution plated were too numerous to count. Values below or exceeding the detection level were entered as absolute values based 
Table 1. Effects of decontaminants on recovery of mycobacteria from striped bass Morone saxatilis homogenates plated on Lowenstein-Jensen medium. Incubation was at $30^{\circ} \mathrm{C}$ for $2 \mathrm{mo}$. Values in parentheses indicate number of homogenates positive for mycobacteria/total number of homogenates

\begin{tabular}{|lccc|}
\hline \multirow{2}{*}{$\begin{array}{l}\text { Sample } \\
\text { type }\end{array}$} & \multicolumn{3}{c|}{ Percentage positive using } \\
\cline { 2 - 4 } & $2 \% \mathrm{HCl}$ & $2 \% \mathrm{NaOH}$ & $0.3 \%$ Zephiran $^{\mathrm{TM}}$ \\
\hline Spleen & 44 & 44 & 20 \\
& $(11 / 25)$ & $(11 / 25)$ & $(5 / 25)$ \\
Skin & 50 & 42 & 17 \\
& $(6 / 12)$ & $(5 / 12)$ & $(2 / 12)$ \\
\hline
\end{tabular}

Table 2. Effect of decontamination on recovery on Middlebrook $7 \mathrm{H} 10$ agar of selected mycobacteria isolated from striped bass Morone saxatilis. Data are expressed as colony forming units ( $\mathrm{CFU}$; mean of 2 samples). Two isolates of $\mathrm{My}$ cobacterium scrofulaceum were examined. ID: indeterminate, $<1 \mathrm{CFU} 0.1 \mathrm{ml}^{-1}$ plated, equal to $<1.0 \mathrm{E} 01 \mathrm{CFU} \mathrm{ml}^{-1}$

\begin{tabular}{|c|c|c|c|c|}
\hline \multirow{2}{*}{$\begin{array}{l}\text { Mycobacterium } \\
\text { spp. }\end{array}$} & \multicolumn{4}{|c|}{ CFU ml ${ }^{-1}$ following exposure to } \\
\hline & $\begin{array}{l}\text { Buffer } \\
\text { (control) }\end{array}$ & $\begin{array}{l}2 \% \\
\mathrm{HCl}\end{array}$ & $\begin{array}{c}2 \% \\
\mathrm{NaOH}\end{array}$ & $\begin{array}{c}0.3 \% \\
\text { Zephiran }^{\mathrm{TM}}\end{array}$ \\
\hline M. interjectum & 1.3 E04 & ID & $<1.5 \mathrm{E} 01$ & $3.5 \mathrm{E} 01$ \\
\hline M. marinum & 5.5E03 & 2.6E02 & ID & ID \\
\hline M. peregrinum & $2.4 \mathrm{E} 03$ & ID & ID & ID \\
\hline M. scrofulaceum 1 & $3.5 \mathrm{E} 03$ & $1.0 \mathrm{E} 01$ & ID & ID \\
\hline M. scrofulaceum 2 & $1.7 \mathrm{E} 03$ & $1.0 \mathrm{E} 01$ & ID & ID \\
\hline M. terrae complex & $4.8 \mathrm{E} 03$ & 3.3E01 & $3.7 \mathrm{E} 02$ & 1.8E01 \\
\hline
\end{tabular}

Table 3. Comparison of different media for recovery of mycobacteria from decontaminated striped bass Morone saxatilis homogenates. Incubation was at $30^{\circ} \mathrm{C}$ for $2 \mathrm{mo}$. Values in parentheses indicate number of homogenates positive for mycobacteria/total number of homogenates

\begin{tabular}{|lcccc|}
\hline $\begin{array}{l}\text { Sample } \\
\text { type }\end{array}$ & $\begin{array}{c}\text { Deconta- } \\
\text { minant }\end{array}$ & \multicolumn{4}{c|}{$\begin{array}{c}\text { Percentage positive on } \\
\text { Lowenstein- } \\
\text { Jensen }\end{array}$} & $\begin{array}{c}\text { Middle- } \\
\text { brook 7H10 }\end{array}$ & $\begin{array}{c}\text { Blood } \\
\text { agar }\end{array}$ \\
\hline Spleen & $2 \% \mathrm{NaOH}$ & 39 & 11 & 3 \\
& & $(14 / 36)$ & $(4 / 36)$ & $(1 / 36)$ \\
& $2 \% \mathrm{HCl}$ & 38 & 12 & 12 \\
& & $(12 / 32)$ & $(4 / 32)$ & $(4 / 32)$ \\
Skin & $2 \% \mathrm{NaOH}$ & 47 & 12 & 12 \\
& & $(8 / 17)$ & $(2 / 17)$ & $(2 / 17)$ \\
& $2 \% \mathrm{HCl}$ & 50 & 19 & 19 \\
& & $(8 / 16)$ & $(3 / 16)$ & $(3 / 16)$ \\
\hline
\end{tabular}

on the lowest level of sensitivity or the highest dilution plated.

Reference cultures. Growth and biochemical testing included reference cultures Mycobacterium avium (M1), M. chelonae (M3), M. flavescens (M4), M. fortuitum (M6), M. gordonae (M8), M. kansasii (M10), M. marinum (M11), M. nonchromogenicum (M14), M. phlei (M15), M. scrofulaceum (M17), M. simiae
(M19, M20) and M. terrae (M21) obtained from the Environmental Protection Agency, Cincinnati, Ohio, and Consolidated Laboratory Services, Commonwealth of Virginia, Richmond, Virginia.

Fish age determination. Fish age was estimated using data provided by the Anadromous Fishes Research Program (VIMS) correlating total length and age based on fish scale assessment for striped bass collected during the study period. Age was determined by linear regression $(y=-2.148+0.013 x, p=<0.0001$, $\mathrm{r}^{2}=0.939$, df = 9406).

Histology. Skin and spleen samples were processed for routine paraffin histology (Prophet et al. 1994) and stained with haematoxylin and eosin (H\&E). Selected sections were stained using Ziehl Neelsen's method for acid-fast bacteria. A minimum of 9 random sections of H\&E stained splenic tissue for each fish was examined at $40 \times$ for the presence and number of granulomas.

Data analysis. All statistical analyses were performed with Statview (SAS Institute).

\section{RESULTS}

\section{Initial samples}

Homogenates prepared from fish exhibiting skin lesions and plated on multiple media i.e. BA, LJ and MDA, yielded mycobacteria from $58 \%$ of spleen ( $\mathrm{n}=$ $25 / 43)$ and $55 \%$ of skin lesion ( $n=12 / 22)$ samples. Mycobacterial detection was significantly affected by the method of decontamination (chi-square, $\mathrm{p}=$ 0.0285). Recovery of mycobacteria on LJ (Table 1) following $\mathrm{HCL}$ and $\mathrm{NaOH}$ treatments was greater than that obtained with Zephiran ${ }^{\mathrm{TM}}$, which was less effective in reducing mold contaminants.

Treatment of suspensions of pure cultures with decontamination agents resulted in 1 to 3 log reductions in CFU (Table 2). Observed adverse effects of $\mathrm{HCl}$ and $\mathrm{NaOH}$ were least on Mycobacterium marinum and $M$. terrae complex, respectively.

Detection of mycobacteria from decontaminated samples was significantly affected by culture medium employed (chi-square, $\mathrm{p}<0.0001$ ). Recovery for samples incubated at $30^{\circ} \mathrm{C}$ was highest on LJ medium compared to MDA and BA, which yielded similar percent detection (Table 3). Overgrowth by molds and non-acid-fast bacteria on all 3 media often precluded incubation for the entire 2 mo period.

Randomly selected samples of spleen $(n=22)$ and skin lesion $(n=14)$ tissue decontaminated using the aforementioned methods were all negative when plated on MMDA. Individual spleen and skin samples plated in parallel on LJ yielded mycobacteria in 46 (10/22) and $29 \%(4 / 14)$ of samples, respectively. Sixty-seven 
Table 4. Growth of mycobacterial reference cultures and mycobacteria isolated from striped bass Morone saxatilis on modified Middlebrook 7H10 agar. Broth suspensions of mycobacteria from reference cultures or cultures isolated from decontaminated fish tissue were streaked on Middlebrook 7H10 agar (MDA) modified to contain $0.025 \%$ malachite green, $0.04 \%$ cycloheximide and $0.0035 \%$ nalidixic acid (MMDA) (Teska et al. 1997) and incubated at $30^{\circ} \mathrm{C}$ for 2 mo. Control = growth of culture on MDA. In the good growth category, individual colonies were easily observed without magnification; in poor growth, individual colonies were only visible with the aid of a stereoscopic microscope. Values in parentheses indicate number positive for mycobacteria/total number

\begin{tabular}{|c|c|c|c|c|}
\hline $\begin{array}{l}\text { Culture source } \\
\text { Mycobacterium spp. }\end{array}$ & $\begin{array}{l}\text { No. of } \\
\text { isolates }\end{array}$ & Good & $\begin{array}{l}\text { Growth } \\
\text { Poor }\end{array}$ & None \\
\hline \multicolumn{5}{|l|}{ Reference } \\
\hline M. avium & 1 & & 1 & \\
\hline M. chelonae & 1 & 1 & & \\
\hline M. flavescens & 1 & & & 1 \\
\hline M. fortuitum & 2 & 2 & & \\
\hline M. gordonae & 1 & & 1 & \\
\hline M. intracellulare & 1 & & 1 & \\
\hline M. kansasii & 1 & & & 1 \\
\hline M. marinum & 3 & & 3 & \\
\hline M. nonchromogenicum & 1 & & 1 & \\
\hline M. phlei & 1 & & 1 & \\
\hline M. scrofulaceum & 2 & 2 & & \\
\hline M. simiae & 2 & 1 & 1 & \\
\hline M. terrae & 1 & & 1 & \\
\hline Percentage & & $\begin{array}{c}33 \\
(6 / 18)\end{array}$ & $\begin{array}{c}56 \\
(10 / 18)\end{array}$ & $\begin{array}{c}11 \\
(2 / 18)\end{array}$ \\
\hline \multicolumn{5}{|l|}{ Fish } \\
\hline M. flavescens & 4 & & 4 & \\
\hline M. gordonae & 3 & & 3 & \\
\hline M. interjectum & 13 & 3 & 9 & 1 \\
\hline M. marinum & 11 & & 9 & 2 \\
\hline M. peregrinum & 1 & & 1 & \\
\hline M. scrofulaceum & 12 & 3 & 8 & 1 \\
\hline M. szulgai & 2 & 1 & 1 & \\
\hline M. terrae complex & 20 & & 20 & \\
\hline Unidentified & 8 & 2 & 5 & 1 \\
\hline Percentage & & $\begin{array}{c}12 \\
(9 / 74)\end{array}$ & $\begin{array}{c}81 \\
(60 / 74)\end{array}$ & $\begin{array}{c}7 \\
(5 / 74)\end{array}$ \\
\hline
\end{tabular}

$(12 / 18)$ and $88 \%(65 / 74)$ of reference and fish isolate cultures, respectively, produced no or poor growth when broth suspensions were inoculated onto MMDA (Table 4). Reference cultures of Mycobacterium chelonae, $M$. fortuitum, $M$. scrofulaceum and $M$. simiae (1/2) and fish isolates resembling $M$. interjectum (3/13) and $M$. scrofulaceum (3/12) produced good growth on MMDA.

A variety of mycobacteria were recovered using the initial protocol of decontamination and incubation at $30^{\circ} \mathrm{C}$ for $2 \mathrm{mo}$. The most frequently recovered splenic isolates from nonaseptically sampled tissues resembled Mycobacterium scrofulaceum $(22 \%, 7 / 32)$ and M. terrae $(19 \%, 6 / 32)$.

\section{Aseptically necropsied samples}

Because experimental exposure of pure culture suspensions to decontamination chemicals showed adverse effects on mycobacterial recovery, aseptic collection of internal tissue samples was initiated. Due to the finding that mycobacteria were more frequently isolated from splenic tissue $(n=16 / 18)$ than liver $(n=$ $2 / 18$ ), and because aseptic sampling of the spleen was easier than that of the kidney, splenic tissue was chosen as the preferred target site. Mycobacteria were recovered from $76 \%(149 / 196)$ of spleen samples that were removed aseptically from striped bass, homogenized, plated directly to MDA and incubated at $23^{\circ} \mathrm{C}$ for 3 mo. Sample homogenates that were enumerated yielded mycobacterial densities exceeding $10^{4} \mathrm{CFU} \cdot \mathrm{g}$ splenic tissue ${ }^{-1}$ in $38 \%(63 / 168)$ of samples. Densities of $\geq 10^{6-7} \mathrm{CFU} \cdot \mathrm{g}$ tissue ${ }^{-1}$ occurred in $13 \%(21 / 168)$ of samples examined.

Ages of fish sampled were positively skewed (Skewness $=1.2)$ from the mean age of 5 yr with $9 \%(17 / 196)$ of samples less than $3 \mathrm{yr}$ and $17 \%$ (34/196) of samples greater than $7 \mathrm{yr}$ of age. Although there was no correlation (Kendall Tau, p > 0.05) between age and log $\mathrm{CFU} \mathrm{g}^{-1}$, mycobacterial densities differed significantly between age groups (Kruskal-Wallis, p < 0.0001). The youngest and oldest fish had both the lowest mean counts and lowest prevalence and, conversely, the 2 middle groups had the highest counts and prevalence (Table 5).

Slowly growing mycobacteria recovered from splenic tissue were grouped using colony pigmentation, a major phenotypic feature, and niacin and nitrate reductase production (Table 6). The dominant mycobacterium recovered, Group A, included isolates that were used to define the new species Mycobacterium

Table 5. Splenic densities and prevalence of mycobacteria in striped bass Morone saxatilis as a function of age. In the first column, values in parentheses indicate total number of fish in age group. In the last column, values in parentheses indicate number of fish positive for mycobacteria/total number fish examined in age group. SD: standard deviation

\begin{tabular}{|c|c|c|c|c|}
\hline \multirow[t]{2}{*}{$\begin{array}{l}\text { Age group } \\
\text { (yr) }\end{array}$} & \multirow{2}{*}{$\begin{array}{c}\text { Mean } \\
\text { weight } \\
\text { (g) }\end{array}$} & \multirow{2}{*}{$\begin{array}{l}\text { Mean } \\
\text { length } \\
(\mathrm{mm})\end{array}$} & \multicolumn{2}{|c|}{$\begin{array}{l}\text { Culture positive } \\
\text { for mycobacteria }\end{array}$} \\
\hline & & & Mean CFU g ${ }^{-1}$ & $1 \%$ \\
\hline $\begin{array}{l}<3.0 \\
(16)\end{array}$ & 288 & 310 & $\begin{array}{c}150 \\
\mathrm{SD}=34\end{array}$ & $\begin{array}{c}19 \\
(3 / 16)\end{array}$ \\
\hline $\begin{array}{l}3.0-4.9 \\
(119)\end{array}$ & 1113 & 485 & $\begin{array}{c}6810 \\
\mathrm{SD}=51\end{array}$ & $\begin{array}{c}90 \\
(107 / 119)\end{array}$ \\
\hline $\begin{array}{l}5.0-6.9 \\
(25)\end{array}$ & 2137 & 596 & $\begin{array}{c}2120 \\
\mathrm{SD}=50\end{array}$ & $\begin{array}{c}80 \\
(20 / 25)\end{array}$ \\
\hline $\begin{array}{l}\geq 7.0 \\
(34)\end{array}$ & 7655 & 892 & $\begin{array}{c}180 \\
\mathrm{SD}=44\end{array}$ & $\begin{array}{c}47 \\
(16 / 34)\end{array}$ \\
\hline
\end{tabular}


shottsii (Rhodes et al. 2003). M. shottsii was isolated alone or in combination with one or more other mycobacteria in $57 \%$ (109/192) of the fish examined. Mycobacteria Group B and F were the second most frequently encountered types, each occurring in $12 \%$ (24/192) of the fish. Biochemical reactions and mycolic acid profiles of Group B isolates were similar to those of M. montefiorense, a moray eel pathogen (Gymnothorax funebris and G. moringa) (Herbst et al. 2001, Levi et al. 2003), and M. triplex, a human pathogen (Floyd et al. 1996). Group F isolates, similar to $M$. shottsii except for chromogenicity and distinguishable from $M$. shottsii on the basis of 3 genetic loci, are described in another publication (Rhodes et al. 2004) All other slowly growing types had a frequency of occurrence of $\leq 8 \%$. Rapidly growing mycobacterial isolates (data not shown) were present in $4 \%(8 / 192)$ of the fish.

With the exception of Group G isolates, which exhibited phenotypic traits consistent with Mycobacterium marinum, all other mycobacteria were more frequently isolated in combination with $M$. shottsii than alone. M. marinum was detected in only $3 \%$ of samples, and most frequently as a monoinfection.

Mean densities of Mycobacterium shottsii, approximately $10^{4} \mathrm{CFUg}^{-1}$ in monoinfections and polyinfec- tions (Table 7), were significantly higher than densities of non M. shottsii (Wilcoxon, p < 0.0001). Mycobacterium shottsii occurred at concentrations $\geq 10^{4} \mathrm{CFU} \mathrm{g}^{-1}$ in $33 \%(56 / 168)$ of enumerated samples.

Non-Mycobacterium shottsii infections exceeded $\geq 10^{4} \mathrm{CFU} \mathrm{g}^{-1}$ in only $5 \%(9 / 168)$ of enumerated samples. M. marinum was the only species recovered in 4 of these 9 samples and occurred at densities $>10^{6}$ $\mathrm{CFU} \cdot \mathrm{g}$ spleen $^{-1}$. One of the $M$. marinum infected fish had splenic granulomas and none presented with external signs. Isolates resembling $M$. montefiorense/M. triplex were present in 3 fish as either the sole species or as the numerically dominant species in a mixed mycobacterial infection. Group D isolates resembling $M$. scrofulaceum on the basis of biochemical tests and HPLC analysis was recovered as the numerically dominant species from 1 fish. An unidentified photochromogenic isolate, Group $\mathrm{H}$, was recovered at elevated densities from 1 sample. Splenic granulomas and petechiae were present in 3 and 2 samples, respectively, of the non $M$. marinum infected fish.

Other mycobacteria recovered, Groups C and E, resembled Mycobacterium interjectum and $M$. szulgai on the basis of biochemical and mycolic acid characteristics.

Table 6. Characteristics of slowly growing mycobacteria recovered from spleens of aseptically necropsied striped bass Morone saxatilis. Values in parentheses indicate number of splenic homogenates positive for mycobacteria/total number homogenates cultured for mycobacteria and isolates characterized $(\mathrm{n}=192)$. Resulting mycobacterial isolates are characterized using biochemical tests. Sample homogenates were spread plated onto Middlebrook $7 \mathrm{H} 10$ agar with oleic acid, albumin, dextrose and catalase (OADC) or albumin, dextrose and catalase (ADC) enrichment and incubated at 23 and $30^{\circ} \mathrm{C}$ for 3 mo. Niacin: niacin production; $\mathrm{NO}_{3}$ red.: nitrate reductase production; +: at least $85 \%$ isolates positive; -: less than $15 \%$ positive; v: 15 to $84 \%$ positive

\begin{tabular}{|c|c|c|c|c|c|c|c|c|}
\hline \multirow{3}{*}{ Test } & \multirow{2}{*}{\multicolumn{3}{|c|}{ Nonpigmented }} & \multirow{2}{*}{\multicolumn{2}{|c|}{$\begin{array}{l}\text { Phenotypic group } \\
\text { Scotochromogenic }\end{array}$}} & \multirow{2}{*}{\multicolumn{3}{|c|}{ Photochromogenic }} \\
\hline & & & & & & & & \\
\hline & $\begin{array}{c}\mathrm{Niacin}+ \\
\mathrm{NO}_{3} \text { red.- } \\
\text { Group A }\end{array}$ & $\begin{array}{l}\text { Niacin - } \\
\mathrm{NO}_{3} \text { red.+ } \\
\text { Group B }\end{array}$ & $\begin{array}{c}\text { Niacin - } \\
\mathrm{NO}_{3} \text { red.- } \\
\text { Group C }\end{array}$ & $\begin{array}{l}\text { Niacin - } \\
\mathrm{NO}_{3} \text { red.- } \\
\text { Group D }\end{array}$ & $\begin{array}{l}\text { Niacin - } \\
\mathrm{NO}_{3} \text { red.+ } \\
\text { Group E }\end{array}$ & $\begin{array}{l}\text { Niacin + } \\
\mathrm{NO}_{3} \text { red.- } \\
\text { Group F }\end{array}$ & $\begin{array}{l}\text { Niacin - } \\
\mathrm{NO}_{3} \text { red.- } \\
\text { Group G }\end{array}$ & $\begin{array}{c}\text { Niacin v } \\
\mathrm{NO}_{3} \text { red.+ } \\
\text { Group H }\end{array}$ \\
\hline \multicolumn{9}{|l|}{ Arylsulfatase } \\
\hline $3 \mathrm{~d}$ & - & - & - & - & $\mathrm{v}$ & - & $\mathrm{v}$ & - \\
\hline $14 \mathrm{~d}$ & - & $\mathrm{v}$ & $\mathrm{v}$ & $\mathrm{v}$ & + & - & + & + \\
\hline \multicolumn{9}{|l|}{ Catalase } \\
\hline Semi-quantitative & $\mathrm{v}$ & + & + & + & + & - & $\mathrm{v}$ & $\mathrm{v}$ \\
\hline Heat-stable $\left(68^{\circ} \mathrm{C}\right)$ & - & + & + & + & + & $\mathrm{v}$ & $\mathrm{v}$ & + \\
\hline \multicolumn{9}{|l|}{ Pyrazinamidase } \\
\hline $4 \mathrm{~d}$ & - & - & - & $\mathrm{v}$ & $\mathrm{v}$ & - & $\mathrm{v}$ & - \\
\hline $7 \mathrm{~d}$ & - & - & $\mathrm{v}$ & $\mathrm{v}$ & $\mathrm{v}$ & - & + & $\mathrm{v}$ \\
\hline Tween & - & - & - & - & - & - & $\mathrm{v}$ & - \\
\hline Urease & + & $\mathrm{v}$ & + & $\mathrm{v}$ & $\mathrm{v}$ & + & + & + \\
\hline \multicolumn{9}{|c|}{ Percentage occurrence } \\
\hline Mono-infection & $\begin{array}{c}32 \\
(62 / 192)\end{array}$ & $\begin{array}{c}2 \\
(4 / 192)\end{array}$ & $\begin{array}{c}1 \\
(2 / 39192)\end{array}$ & $\begin{array}{c}1 \\
(2 / 192)\end{array}$ & $\begin{array}{c}<1 \\
(1 / 192)\end{array}$ & $\begin{array}{c}4 \\
(8 / 192)\end{array}$ & $\begin{array}{c}2 \\
(4 / 192)\end{array}$ & $\begin{array}{c}2 \\
(4 / 192)\end{array}$ \\
\hline Poly-infection & $\begin{array}{c}25 \\
(47 / 192)\end{array}$ & $\begin{array}{c}10 \\
(20 / 192)\end{array}$ & $\begin{array}{c}5 \\
(9 / 192)\end{array}$ & $\begin{array}{c}7 \\
(13 / 192)\end{array}$ & $\begin{array}{c}5 \\
(9 / 192)\end{array}$ & $\begin{array}{c}8 \\
(16 / 192)\end{array}$ & $\begin{array}{c}1 \\
(2 / 192)\end{array}$ & $\begin{array}{c}5 \\
(10 / 192)\end{array}$ \\
\hline Total & $\begin{array}{c}57 \\
(109 / 192)\end{array}$ & $\begin{array}{c}12 \\
(24 / 192)\end{array}$ & $\begin{array}{c}6 \\
(11 / 192)\end{array}$ & $\begin{array}{c}8 \\
(15 / 192)\end{array}$ & $\begin{array}{c}5 \\
(10 / 192)\end{array}$ & $\begin{array}{c}12 \\
(24 / 192)\end{array}$ & $\begin{array}{c}3 \\
(6 / 192)\end{array}$ & $\begin{array}{c}7 \\
(14 / 192)\end{array}$ \\
\hline
\end{tabular}


Table 7. Recovery of mycobacteria from aseptically sampled striped bass Morone saxatilis splenic tissue using incubation at 23 and $30^{\circ} \mathrm{C}$ for $3 \mathrm{mo}$. Values in parentheses indicate number of splenic homogenates positive for mycobacteria/total number of homogenates cultured for mycobacteria and isolates characterized $(\mathrm{n}=192)$. Sample homogenates spread plated onto Middlebrook 7H10 agar with ADC or OADC enrichment. In Mean CFU g ${ }^{-1}$ column, 119 splenic homogenates of 168 splenic samples submitted for enumeration were culture positive. M. shottsii: Mycobacterium shottsii

\begin{tabular}{|c|c|c|c|c|}
\hline \multirow{2}{*}{ Mycobacterium } & \multicolumn{3}{|c|}{ _ Percentage- } & \multirow{2}{*}{ Mean CFU g ${ }^{-1}$} \\
\hline & Culture & External sign & Splenic granuloma & \\
\hline Culture positive & $\begin{array}{c}\mathbf{7 6} \\
(145 / 192)\end{array}$ & $\begin{array}{c}\mathbf{4 5} \\
(86 / 192)\end{array}$ & $\begin{array}{c}\mathbf{5 4} \\
(104 / 192)\end{array}$ & \\
\hline \multicolumn{5}{|l|}{ Monoinfection } \\
\hline M. shottsii & $\begin{array}{c}32 \\
(62 / 192)\end{array}$ & $\begin{array}{c}19 \\
(37 / 192)\end{array}$ & $\begin{array}{c}24 \\
(46 / 192)\end{array}$ & $\begin{array}{l}23600 \\
\mathrm{n}=48\end{array}$ \\
\hline Non-M. shottsii & $\begin{array}{c}12 \\
(23 / 192)\end{array}$ & $\begin{array}{c}6 \\
(11 / 192)\end{array}$ & $\begin{array}{c}6 \\
(11 / 192)\end{array}$ & $\begin{array}{c}1400 \\
\mathrm{n}=22\end{array}$ \\
\hline \multicolumn{5}{|l|}{ Polyinfection } \\
\hline $\begin{array}{l}\text { M. shottsii and } \\
\text { non-M. shottsii }\end{array}$ & $\begin{array}{c}25 \\
(47 / 192)\end{array}$ & $\begin{array}{c}18 \\
(35 / 192)\end{array}$ & $\begin{array}{c}21 \\
(40 / 192)\end{array}$ & $\begin{array}{c}24700(M . \text { shottsii) } \\
210 \text { (non-M. shottsii) } \mathrm{n}=39\end{array}$ \\
\hline Non-M. shottsii & $\begin{array}{c}7 \\
(13 / 192)\end{array}$ & $\begin{array}{c}2 \\
(3 / 192)\end{array}$ & $\begin{array}{c}4 \\
(7 / 192)\end{array}$ & $\begin{array}{c}2400 \\
\mathrm{n}=10\end{array}$ \\
\hline Culture negative & $\begin{array}{c}\mathbf{2 4} \\
(47 / 192)\end{array}$ & $\begin{array}{c}\mathbf{9} \\
(18 / 192)\end{array}$ & $\begin{array}{c}\mathbf{5} \\
(9 / 192)\end{array}$ & \\
\hline
\end{tabular}

Skin lesions ranged in severity from small areas of scale loss, often with associated melanotic foci, to infrequently seen large shallow ulcers with hyperpigmented margins. Although external signs and splenic granulomas were more frequent in culture-positive compared with culture-negative fish, many were negative for both parameters (Table 7).

Rapidly growing mycobacteria generally occurred at densities $\leq 10^{2} \mathrm{CFU} \mathrm{g}^{-1}$ and were co-isolated with Mycobacterium shottsii on 5 of 8 occasions. All isolates except 1 were pigmented and none had biochemical and growth characteristics resembling known rapidly growing fish pathogens, e.g. M. fortuitum.

Gram-positive cocci were recovered at $\leq 10^{4-5} \mathrm{CFU}$ $\mathrm{g}^{-1}$ from aseptically necropsied spleens on 5 occasions. In 3 of these instances Mycobacterium shottsii was co-isolated.

Mycobacterium terrae, frequently isolated in nonaspetically collected samples, was never observed when splenic tissue was sampled aseptically.

\section{Skin scrapings}

Skin scrapings from 15 fish with skin lesions were decontaminated with $\mathrm{NaOH}$ and cultured for mycobacteria. Granulomas were observed histologically in 11 of 15 skin specimens and in all corresponding spleen samples. Mycobacterium shottsii was isolated from all 15 skin samples and was the only mycobacterium recovered from 12 samples. Isolates resembling $M$. gordonae and an unidentified scotochromogen were recovered from 2 and 1 fish, respectively. $M$. shottsii CFUs on plates inoculated with $<0.05 \mathrm{~g}$ skin scrapings ranged from a few to too numerous to count, whereas non- $M$. shottsii were represented by 1 or 2 colonies in each of the 3 polyinfections. M. shottsii was recovered from all corresponding spleen samples at a mean density of $4.0 \times$ $10^{5} \mathrm{CFU} \mathrm{g}^{-1}$.

\section{DISCUSSION}

Diagnosis of mycobacteriosis in fish is frequently based on the presence of acid-fast bacilli in histological sections, and culture is not always performed or successful (Dalsgaard et al. 1992, Frerichs 1993). However, pathogenic mycobacteria may be refractory during infection to staining with standard acid-fast techniques, so reliance on histological diagnosis may underestimate disease prevalence (Gauthier et al. 2003). In addition, paramount to identifying an infectious disease is recovery of an aetiological agent. Culturing from diseased tissue allows for isolation, subsequent genotypic and phenotypic characterization of the suspect pathogen(s) and, ultimately, challenge studies to confirm pathogenicity and fulfill Koch's postulates. Determination of mycobacterial densities by plating provides information regarding both intensity of infection and the presence of polyinfections. In the present study of the epizootic of mycobacteriosis in striped bass of the Chesapeake Bay, we isolated and enumerated mycobacteria using a facile method based 
on aseptic necropsy. During the course of this study the significance of various aspects of sampling and culture methodology on recovery of the aetiological agent(s) was examined.

During necropsy there is significant potential for introduction of external mycobacterial contaminants whose presence can complicate isolation/identification of the true pathogen. Initial samples examined in this study were received in the laboratory following invasive field procedures that compromised the sterility of internal organs and necessitated chemical decontamination to reduce or eliminate background overgrowth that would prevent detection of slowly growing mycobacteria. Treatment of laboratory suspensions of pure cultures of mycobacteria with $\mathrm{NaOH}, \mathrm{HCl}$ and Zephiran $^{\mathrm{TM}}$ demonstrated marked susceptibility of some mycobacteria to these agents. These findings agree with previous reports of detrimental effects of decontamination on mycobacterial recovery (Brooks et al. 1984, Schulze-Robbecke et al. 1991, Dalsgaard et al. 1992, Yajko et al. 1993, Kamala et al. 1994). Despite the potential loss of culturability from decontamination, treatment of internal tissue samples is still recommended (Chinabut 1999). Our study demonstrates that decontamination can be avoided by careful use of aseptic necropsy to prevent the introduction of external mycobacteria.

Isolation of mycobacteria from skin lesions requires treatment to kill other surface microbiota. Although Bragg et al. (1990) reported better growth of Mycobacterium fortuitum from fish homogenates decontaminated with $2 \% \mathrm{HCl}$ compared with $4 \% \mathrm{NaOH}$, we observed no statistical difference in mycobacterial recovery for tissues decontaminated with $2 \% \mathrm{HCl}$ or $2 \% \mathrm{NaOH}$. Modification of our decontamination procedure to reduce treatment time yielded a method that was effective in recovering mycobacteria from skin lesions. Investigators should be aware that mycobacterial susceptibility to disinfection varies according to species, a phenomenon reported by others (Brooks et al. 1984, Dalsgaard et al. 1992) and supported by results for spiked suspensions of fish isolates examined in this study. Varying susceptibilities to decontaminants can result in biased isolation and recovery (Kazda 1983) and reduced enumeration efficiency.

A variety of media for the cultivation of mycobacteria are characterized by various degrees of selectivity and recovery. The selective medium, MMDA, formulated for enumeration of Mycobacterium abscessus (Teska et al. 1997), was not effective for recovery of the majority of mycobacteria from striped bass. The ability of MMDA to support growth of various reference strains and field isolates varied within and among species. Although MDA was not as effective as LJ medium for recovery of mycobacteria from decontaminated sam- ples, i.e. 15 versus $44 \%$, respectively, it provided effective recovery of mycobacteria from samples not subjected to decontamination, i.e. $76 \%$ of all striped bass examined. MDA also enhanced recovery of fish isolates compared with BA medium. Additional advantages of direct plating on MDA plates rather than LJ medium included the ability to enumerate colonies and to distinguish different colony types, which facilitated detection of mixed infections. Mixed infections may be difficult to detect on slants due to overgrowth by numerically dominant or faster-growing mycobacteria.

Appropriate incubation temperature and duration are crucial to recovery of environmental mycobacteria. Human diagnostic protocols call for incubation of mycobacterial cultures at 35 or $37^{\circ} \mathrm{C}$, with the exception of suspected Mycobacterium marinum or $M$. ulcerans infections, when incubation at 25 to $33^{\circ} \mathrm{C}$ is indicated (Master 1995). For recovery of mycobacteria from fish, we recommend incubation at both 23 and $30^{\circ} \mathrm{C}$ if possible, and incubation at $23^{\circ} \mathrm{C}$ if only one temperature is available. In this study, the most frequently recovered mycobacteria, $M$. shottsii and a chromogenic mycobacterium closely resembling M. shottsii (Rhodes et al. 2003), grew poorly or not at all at $30^{\circ} \mathrm{C}$, and required 2 to 3 mo incubation on primary culture. All other mycobacteria isolated from striped bass grew both at 23 and $30^{\circ} \mathrm{C}$, with growth rates enhanced at the latter temperature.

Plating of tissue homogenate on a nonselective medium such as BHI is recommended in order to detect a nonmycobacterial infection or sample contamination. In this study, high densities of nonmycobacteria in splenic tissue occurred infrequently, and when present were characterized by gram-positive cocci. Additional cultural and histological studies are needed to determine whether these cocci are of pathological significance.

Fish mycobacteriosis is a chronic progressive disease that may take several years to progress from a covert state to clinical illness (Austin \& Austin 1987). A histological investigation of Chesapeake Bay striped bass showed that disease prevalence in 3 to 5 yr old fish was higher than in younger fish (Cardinal 2001). Our culture data likewise demonstrated that fish less than $3 \mathrm{yr}$ old exhibited a lower frequency of infection, and that prevalence declined from $90 \%$ in the 3 to 4.9 age group to $47 \%$ in fish $7 \mathrm{yr}$ and older. Kaattari (I. M. Kaattari unpubl. data) observed that more striped bass 6 yr or older were positive by PCR and nested PCR than by culture. It is possible that in older fish, viable mycobacteria are present at very low densities, or PCR is detecting nonviable mycobacterial cells.

Histological evaluation of internal organs from Pacific coast striped bass revealed that, despite a high prevalence of visceral acid-fast granulomas, fish did 
not display gross external signs of disease (Sakanari et al. 1983). Similarly, the majority of Chesapeake Bay striped bass with splenic granulomas did not exhibit external lesions (Cardinal 2001). However, in the latter study, dermal lesion prevalence significantly increased with the intensity of splenic infection, i.e. abundance of granulomas, suggesting that external lesions are an expression of late-stage mycobacteriosis. This has also been proposed by Chinabut (1999). In our study, fish displaying external signs of disease typically had splenic mycobacterial densities of $>10^{5} \mathrm{CFU} \mathrm{g}^{-1}$.

Phenotypic characterization revealed a variety of mycobacteria in aseptically processed spleen samples from this study. The most frequently isolated mycobacterium was Mycobacterium shottsii, a recently described new species (Rhodes et al. 2001, 2003), present in $57 \%$ of striped bass examined. Approximately $25 \%$ of fish harboured 1 or more other types of mycobacteria, generally at concentrations 1 or 2 orders of magnitude lower than $M$. shottsii. $M$. shottsii was also the dominant mycobacterium recovered from skin lesions. Frequency of recovery and quantitative data from these wild populations of striped bass suggest $M$. shottsii as an aetiological agent of mycobacteriosis.

In a previous study, Mycobacterium shottsii persisted for $45 \mathrm{wk}$ in the spleens of experimentally infected hatchery-reared striped bass, but there was very little granuloma formation and no marked multiplication of mycobacteria (Gauthier et al. 2003). It is possible that environmental parameters of the challenge study, i.e. a flow-through freshwater system maintained at 18 to $23^{\circ} \mathrm{C}$ with well-fed fish, were not favorable for $M$. shottsii disease development over the time course of the study. The very slow growth characteristic of $M$. shottsii suggests that development of disease in exposed young fingerlings may require a longer period of infection. Environmental stressors, e.g. elevated temperature or reduced food ration, may also be necessary for development of disease.

Mycobacteria resembling Mycobacterium montefiorense/M. triplex and a previously unrecognized species related to $M$. shottsii were the next most frequently encountered types in splenic tissue. Granulomatous skin lesions in moray eel were attributed to an $M$. triplex-like organism that did not grow above $30^{\circ} \mathrm{C}$ (Herbst et al. 2001), a temperature preference shared with many of our isolates and unlike M. triplex isolated from humans (Floyd et al. 1996). Eel isolates were subsequently distinguished on the basis of 3 genetic loci from $M$. triplex, and constitute a new species, M. montefiorense sp. nov. (Levi et al. 2003). Additional phenotypic and genotypic studies are in progress to determine the relationship of $M$. triplex and $M$. montefiorense to similar mycobacteria from striped bass. The Mycobacterium sp. resembling
M. shottsii differed by producing a light-yellow/gold pigment upon prolonged incubation and following light exposure. Based on sequencing results for 3 genetic loci, these isolates are different from $M$. shottsii and are proposed to constitute a new species (M. W. Rhodes unpubl. data).

Mycobacterium marinum, considered to be one of the primary agents of fish mycobacteriosis (Frerichs 1993, Chinabut 1999), was recovered in only $3 \%$ (6/192) of spleen samples examined. However, whereas most mycobacteria other than $M$. shottsii occurred as polyinfections (typically with $M$. shottsii), M. marinum was present more often as a mono-infection and at elevated densities. Exposure studies (Gauthier et al. 2003) demonstrated that M. marinum multiplied rapidly and produced severe pathology. The high growth rate of $M$. marinum may enable it to outcompete slowly growing species.

Mycobacterium marinum is recognized as a causative agent of a variety of infections in the extremities, e.g. skin, soft tissue, tendon, and bones, in healthy individuals with a history of exposure and trauma such as wounds from handling fish, and sometimes results in disseminated infections in the immunocompromised (Falkinham 1996, Anonymous 1997). Other mycobacteria recovered included isolates with phenotypic profiles similar to species known to cause disease in humans: Group B: M. triplex; Group C: M. interjectum; Group D: M. scrofulaceum, and Group E: M. szulgai. (Falkinham 1996, Floyd et al. 1996, Horsburgh 1996, Anonymous 1997, Zenone et al. 1999, Hazra et al. 2001). However, assignment of these environmental isolates to existing species is tenuous and requires additional genotypic studies. Mediel et al. (2000) also reported the inability to speciate mycobacteria isolated from fish on the basis of biochemical or restriction fragment length polymorphism analysis pattterns. With the development of new molecular tools that have enhanced discriminatory power, there has been an explosion of new species in the Mycobacterium taxon (Tortoli 2003). Reliance solely on phenotypic tests and diagnostic keys developed primarily for clinical isolates to classify environmental isolates may be inappropriate.

Neither causative factors of the ongoing mycobacterial epizootic of striped bass in the Chesapeake Bay, nor the impact on fish stocks, are known. Possible transmission mechanisms of fish mycobacteriosis include oral, via contaminated food, surface, via damaged skin and transovarian (Belas et al. 1995). The latter warrants investigation since the striped bass population in the Chesapeake Bay represents a major restocking effort. Although there are no overt signs suggesting mycobacteriosis in other fish populations resident in the Chesapeake Bay, very few samples 
have been submitted to culture analysis (Rhodes \& Kaattari unpubl. findings). In order to study the ecology of mycobacteria recovered from striped bass, improved methods for application to water samples are needed. Experiments conducted to evaluate methodology for the recovery of mycobacteria from water samples collected during a fish challenge study (Gauthier et al. 2003) showed that sensitivity differences to decontamination chemicals (i.e. $\mathrm{NaOH}, \mathrm{H}_{2} \mathrm{SO}_{4,}$, oxalic acid) or selective agents (i.e. cetylpyridinium chloride, primaricin) in culture media resulted in biased recovery and poor detection of slowly growing mycobacteria (M. W. Rhodes unpubl. data). Possible changes in environmental factors affecting mycobacterial populations (i.e. loadings, geographic and seasonal distributions and species composition) and the health status of striped bass have not been identified. Addressing these questions will require not only cultural methods but also development of specific and quantitative molecular tools (Knibb et al. 1993, Belas et al. 1995, Talaat et al. 1999, and Kaattari et al. 2004).

Acknowledgements. We thank Dana Booth, Jennifer Dillon, Luke Iwanowicz, P. Blake and D. Zwerner for technical assistance as well as Erin Burge, Chris Hager, the VIMS Department of Fisheries, the American Striper Association and the Coastal Conservation Association for assistance in obtaining samples. The VIMS Anadromous Fishes Research Program provided data for age determination. The authors gratefully acknowledge the assistance of Mitchell Yakrus and Ray Butler (Centers for Disease Control and Prevention, Atlanta) in performing HPLC analyses. This work was supported by the Virginia Marine Resources Commission, the US Geological Survey Cooperative Research Agreement, and VIMS (Contribution No. 2605 of the Virginia Institute of Marine Science).

\section{LITERATURE CITED}

Anonymous (1981) Interstate fisheries management plan for the striped bass. Fisheries Management Report 1, Atlantic States Marine Fisheries Commission, Washington, DC

Anonymous (1995) Bacteriological analytical manual. US Food and Drug Administration, AOAC International, Gaithersburg, MD

Anonymous (1997) Diagnosis and treatment of disease caused by nontuberculous mycobacteria. Official statement of the American Thoracic Society. Am J Resp Crit Care Med 156: $\mathrm{S} 1-\mathrm{S} 25$

Austin B, Austin DA (1987) Aerobic gram-positive rods. In: Austin B, Austin DA (eds) Bacterial fish pathogens: disease in farmed and wild fish. Ellis Horwood, John Wiley \& Sons, New York, p 56-96

Backman S, Ferguson HW, Prescott JF, Wilcock BP (1990) Progressive panophthalmitis in chinook salmon, Oncorhynchus tshawytscha (Walbaum): a case report. J Fish Dis 13:345-353

Baya AM (1998) Gram positive bacteria and skin lesions in Chesapeake Bay fish. Proc Workshop Causes and Effects of Ulcerative Lesions in Fish, Easton, MD. Maryland Department of Natural Resources, Oxford, MD, p 11
Baya AM, Romalde JL, Green DE, Navarro RB, Evans J, May EB, Toranzo AE (1997) Edwardsiellosis in wild striped bass from the Chesapeake Bay. J Wildl Dis 33:517-525

Belas R, Faloon P, Hannaford A (1995) Potential applications of molecular biology to the study of fish mycobacteriosis. Annu Rev Fish Dis 5:133-173

Bragg RR, Huchzermeyer HFAK, Hanisch MAM (1990) Mycobacterium fortuitum isolated from three species of fish in South Africa. Onderstepoort J Vet Res 57:101-102

Brooks RW, George KL, Parker BC, Falkinham III JO (1984) Recovery and survival of nontuberculous mycobacteria under various growth and decontamination conditions. Can J Microbiol 30:1112-1117

Butler WR, Guthertz LS (2001) Mycolic acid analysis by highperformance liquid chromatography for identification of Mycobacterium species. Clin Microbiol Rev 14:704-726

Butler WR, Floyd MM, Silcox V, Cage G and 8 others (1996). Standardized method for HPLC identification of mycobacteria. Centers for Disease Control and Prevention, Atlanta, GA

Cardinal JL (2001) Mycobacteriosis in striped bass, Morone saxatilis, from Virginia waters of Chesapeake Bay. MSc thesis, Virginia Institute of Marine Science, College of William and Mary, Gloucester Point, VA

Chinabut S (1999) Mycobacteriosis and Nocardiosis. In: Woo PTK, Bruno DW (eds) Fish diseases and disorders. Viral, bacterial and fungal infections. Vol. 3, CAB International, Wallington, p 319-340

Dalsgaard I, Mellergaard S, Larsen JL (1992) Mycobacteriosis in cod (Gadus morhua L.) in Danish coastal waters. Aquaculture 107:211-219

Falkinham JO III (1996) Epidemiology of infection by nontuberculous mycobacteria. Clin Microbiol Rev 9:177-215

Floyd MM, Guthertz LS, Silcox VA, Duffy PS, Jang Y, Desmond EP, Crawford JT, Butler WR (1996) Characterization of an SAV organism and proposal of Mycobacterium triplex sp. nov. J Clin Microbiol 34:2963-2967

Frerichs GN (1993) Mycobacteriosis:Nocardiosis. In: Inglis V, Roberts RJ, Bromage NR (eds) Bacterial diseases of fish. Institute of Aquaculture, Halsted Press. New York, p 219-233

Gauthier DT, Rhodes MW, Vogelbein WK, Kator H, Ottinger CA (2003) Experimental mycobacteriosis in striped bass Morone saxatilis. Dis Aquat Org 54:105-117

Hazra R, Floyd MM, Sloutsky A, Husson RN (2001) Novel mycobacterium related to Mycobacterium triplex as a cause of cervical lymphadenitis. J Clin Microbiol 39: $1227-1230$

Heckert RA, Elankumaran S, Milani A, Baya A (2001) Detection of a new Mycobacterium species in wild striped bass in the Chesapeake Bay. J Clin Microbiol 39:710-715

Hedrick RP, McDowell T, Groff J (1987) Mycobacteriosis in cultured striped bass from California. J Wildl Dis 23: 391-395

Herbst LH, Costa SF, Weiss LM, Johnson LK, Bartell J, Davis R, Walsh M, Levi M (2001) Granulomatous skin lesions in moray eels caused by a novel Mycobacterium species related to Mycobacterium triplex. Infect Immunol 69: 4639-4646

Horsburgh CR Jr (1996) Epidemiology of disease caused by nontuberculous mycobacteria. Semin Respir Infect 11: 244-251

Kamala T, Paramasivan CN, Herbert D, Venkatesan P, Prabhakar R (1994) Evaluation of procedures for isolation of nontuberculous mycobacteria from soil and water. Appl Environ Microbiol 60:1021-1024

Kazda JF (1983) The principles of the ecology of mycobacte- 
ria. Biology of mycobacteria. In: Ratledge $\mathrm{C}$, Stanford $\mathrm{H}$ (eds) The biology of the mycobacteria. Vol. 2, Academic Press, London, p 323-341

Kent PT, Kubica GP (1985) Public health mycobacteriology: a guide for the level III laboratory. US Department of Health and Human Services, Publication no. (CDC) 86-8230. Centers for Disease Control, Atlanta

Kirkley JE, McConnell KE, Ryan W (2000) Economic aspects of allocating striped bass among competing user groups in Virginia. Report No. 2000-05. Virginia Marine Resources, Newport News, VA

Knibb W, Colorni A, Ankaoua M, Lindell D, Diamant A, Gordin H (1993) Detection and identification of a pathogenic marine mycobacterium from the European seabass Dicentrarchus labrax using polymerase chain reaction and direct sequencing of $16 \mathrm{~S}$ rDNA sequences. Mol Mar Biol Biotechnol 2:225-232

Lansdell W, Dixon B, Smith N, Benjamin L (1993) Isolation of several Mycobacterium species from fish. J Aquat Anim Health 5:73-76

Levi MH, Bartell J, Gandolfo L, Smole SC and 5 others (2003) Characterization of Mycobacterium montefiorense sp. nov., a novel pathogenic mycobacterium from moray eels that is related to Mycobacterium triplex. J Clin Microbiol 41:2147-2152

Lévy-Frébault VV, Portaels F (1992) Proposed minimal standards for the genus Mycobacterium and for description of new slowly growing Mycobacterium species. Int J Syst Bacteriol 42:315-323

Master RN (1995) Mycobacteriology. In: Isenburg HD (ed) Clinical microbiology procedures handbook. Vol.1. American Society for Microbiology, Washington, DC, p 3.0.1-3.16.3

Mediel MJ, Rodriguez V, Codina G, Martin-Casabona N (2000) Isolation of mycobacteria from frozen fish destined for human consumption. Appl Environ Microbiol 66: $3637-3638$

Mitchell AJ (1984) Parasites and diseases of striped bass. In: JP McCraren (ed) The aquaculture of striped bass: a proceedings. University of Maryland Sea Grant Program, College Park, MD, p 177-204

Plumb JA (1991) Major diseases of striped bass and redfish. Vet Hum Toxicol 33:34-39

Prophet EB, Mills B, Arrington JB, Sobin LH (1994) Laboratory methods in histotechnology. Armed Forces Institute of Pathology, American Registry of Pathology, Washington, DC

Rhodes MW, Kator H, Kotob S, van Berkum P and 7 others (2001) A unique Mycobacterium species isolated froom an

Editorial responsibility: David Bruno

Aberdeen, UK epizootic of striped bass (Morone saxatilis). Emerg Infect Dis 7:1-3

Rhodes MW, Kator H, Kotob S, van Berkum P and 6 others (2003) Mycobacterium shottsii sp. nov., a slowly growing species isolated from Chesapeake Bay striped bass (Morone saxatilis). Int J Syst Evol Microbiol 53:421-424

Sakanari JA, Reilly CA, Moser M (1983) Tubercular lesions in Pacific coast populations of striped bass. Trans Am Fish Soc 112:565-566

Schulze-Röbbecke R, Weber A, Fischeder YR (1991) Comparison of decontamination methods for the isolation of mycobacteria from drinking water samples. J Microbiol Methods 14:177-183

Sindermann CJ (1988) Striped bass diseases. In: Sindermann CJ, Lightner DV (eds) Disease diagnosis and control in North American marine aquaculture. Elsevier Scientific Publications, New York, p 354-371

Talaat AM, Trucksis M, Kane AS, Reimschuessel R (1999) Pathogenicity of Mycobacterium fortuitum and Mycobacterium smegmatis to goldfish, Carassius auratus. Vet Microbiol 66:151-164

Teska JD, Twerdok LE, Beaman J, Curry M, Finch RA (1997) Isolation of Mycobacterium abscessus from Japanese medaka. J Aquat Anim Health 9:234-238

Toranzo AE, Barja JL, Potter SA, Colwell RR, Hetrick FM, Crosa JH (1983) Molecular factors associated with virulence of marine vibrios isolated from striped bass in Chesapeake Bay. Infect Immunol 39:1220-1227

Tortoli E (2003) Impact of genotypic studies on mycobacterial taxonomy: the new mycobacteria of the 1990s. Clin Microbiol Rev 16:319-354

Tortoli E, Bartoloni A, Bozzetta E, Burrini C and 5 others (1996) Identification of the newly described Mycobacterium poriferae from tuberculous lesions of snakehead fish (Channa striatus). Comp Immunol Microbiol Infect Dis 19:25-29

Vogelbein W, Zwerner D, Kator H, Rhodes M, Kotob SI, Faisal M (1998) Mycobacteriosis in the striped bass, Morone saxatilis, from Chesapeake Bay. In: Kane AS, Poynton SL (eds) Proc 3rd Symp Aquat Anim Health, Aug 30-Sep 3, 1998, Baltimore. APC Press, Baltimore, MD, p 109

Yajko DM, Nassos PS, Sanders CA, Gonzalez PC and 5 others (1993) Comparison of four decontamination methods for recovery of Mycobacterium avium complex from stools. J Clin Microbiol 31:302-306

Zenone T, Boibeux A, Tigaud S, Fredenucci JF, Vincent V, Chidiac C, Peyramond D (1999) Non-tuberculous mycobacterial tenosynovitis. Scand J Infect Dis 31:221-228

Submitted: December 29, 2003; Accepted: June 11, 2004 Proofs received from author(s): October 1, 2004 